\title{
Eliminating Thrips From In Vitro Shoot Cultures of Apple with Insecticides
}

\author{
Basdeo Bhagwat ${ }^{1}$ and W. David Lane \\ Pacific Agri-Food Research Centre, Agriculture and Agri-Food Canada, \\ Summerland, BC, VOH 1Z0, Canada
}

\begin{abstract}
Additional index words. micropropagation, Malus $\times$ domestica, Frankliniella occidentalis, acephate, dichlorvos, imidacloprid
\end{abstract}

\begin{abstract}
The insecticides acephate, dichlorvos, and imidacloprid were assayed, using in vitro shoot cultures of apple (Malus $\times$ domestica Borkh.), to determine their phytotoxicity at several concentrations and their effectiveness for eradication of the Western Flower Thrip (Frankliniella occidentalis, Pergande) from infested apple shoot cultures. Commercial formulations of acephate (Orthene), dichlorvos (VaportapeII), and imidacloprid (Admire) and a technical grade of imidacloprid were used in the experiments. For acephate and imidacloprid, concentrations of 1 to $80 \mathrm{mg} \cdot \mathrm{L}^{-1}$ a.i. in shoot culture medium were used, while for dichlorvos, a fumigant, particles of the formulated product containing concentrations of 0.7 to $6.4 \mathrm{mg}$ a.i. were suspended in the head space of the $500-\mathrm{mL}$ glass culture jar. Acephate, dichlorvos, and the technical grade of imidacloprid did not cause phytotoxicity and growth of shoot cultures was unaffected at all treatment concentrations tested after a 6-week treatment period. Imidacloprid $\left(20\right.$ to $80 \mathrm{mg} \cdot \mathrm{L}^{-1}$ of the commercial formulation) caused chlorosis at the end of the 6-week treatment period. None of the treatments tested resulted in the death of shoots. Thrips were eradicated by acephate or imidacloprid treatments of $5 \mathrm{mg} \cdot \mathrm{L}^{-1}$ and by dichlorvos treatment of $0.7 \mathrm{mg}$ per $500-\mathrm{mL}$ culture jar. Shoot cultures grew normally after the treatment period. Chemical names used: $O, S$-dimethyl acetylphosphoramidothioate (acephate), 2,2- dichlorovinyl dimethyl phosphate (dichlorvos), 1-(6-chloro-3-pyridylmethyl)- $N$-nitroimidazolidin-2-ylideneamine (imidacloprid).
\end{abstract}

Contamination is the most important cause for losses of in vitro cultures at commercial micropropagation facilities (Cassells, 1986; Boxus and Terzi 1987; Leifert and Waites, 1990; Leifert and Woodward, 1998). Cultures can be contaminated with viruses, bacteria, fungi, yeast, mites and thrips (Knauss and Miller, 1978; Leifert et al., 1994). Thrips and mites often spread microorganisms that contaminate plant tissue cultures. Bacteria are by far the most common and most serious contaminants.

Contamination by thrips is less common but a few invading thrips can develop to high population levels that completely destroy cultures and may often go unnoticed because of their small size. Additionally, thrips may introduce into sterile cultures other contaminants such as bacteria and fungi (Deberch and Maene, 1984; Klocke and Myers, 1984; Blake, 1988). Little information is available concerning control of thrips in in vitro cultures (Klocke and Myers, 1984).

Received for publication 28 Sept. 2001. Accepted for publication 14 May 2002. We acknowledge M. Weis for help with the photography, J. Hall for advice on statistical analysis, T. Lowery for advice on insecticides, and L. Jensen for identification of the thrips. This research was supported by a Matching Investment Initiatives grant from Agriculture and Agri-Food Canada to W.D.L and matching funds from our collaborator, Okanagan Biotechnology. PARC publication number 2138

${ }^{1}$ To whom reprint requests should be sent. E-mail address: Bhagwatb@em.agr.ca
Thrips are common pests of greenhouse and field crops including apple and sweet cherry. They usually feed on actively-growing tissues such as young leaves and terminal buds or flowers and developing fruit. Eggs are laid just below the surfaces of tissues. Thrip's affinity for tight places, like flower buds, and the ability to deposit eggs in plant tissues may prevent decontamination during surface sterilization when in vitro cultures are initiated and makes eradication more difficult if a contact/respiratory insecticide is used. Thrips frequently gain entry to in vitro cultures through loose-fitting closures of culture vessels when they migrate from nearby infested plants.

Damage done by thrips is not always severe, but in a survey done by Blake (1988), $15 \%$ of tissue culture labs had experienced problems with thrips infestation, sometimes quite frequently and with severe consequences. Besides damage done by feeding, thrips may carry fungal spores and bacteria in and on their bodies, inoculating cultures and medium causing serious contamination problems. The presence of thrips in cultures can go undetected for several years, causing losses and reducing the efficiency of commercial labs (Blake, 1988).

The objective of this study was to evaluate the effectiveness of some insecticides with systemic and contact/respiratory modes of accultures and develop a protocol for their use to eliminate thrips from infested cultures without harming the cultures. tion for the control of thrips on apple shoot
Plant material and culture conditions. Shoot cultures of apple cv. Golden Delicious were maintained on a shoot culture medium of Murashige and Skoog (1962) minerals and vitamins (MS), supplemented with $3 \mu \mathrm{M}$ benzyladenine (BA), $87.6 \mathrm{~mm}$ sucrose and $0.6 \%$ Agargel (Sigma Chemical Co., St. Louis). Cultures were maintained in 500-mL jars $(100 \mathrm{~mL}$ medium/jar) closed with plastic lids fitted with $1.0 \mathrm{~cm}$ diameter open cell foam plugs to allow for exchange of gases. Additionally, the junction between the lid and the jar was sealed with a plastic wrap. Cultures were incubated at 25 $\pm 2{ }^{\circ} \mathrm{C}$ with a 16 -h light $/ 8$-h dark photoperiod and light intensity of $18 \mu \mathrm{mol} \cdot \mathrm{m}^{-2} \cdot \mathrm{s}^{-1}$ provided by cool-white fluorescent tubes.

Insecticides. The insecticides used in this investigation were acephate, dichlorvos, and imidacloprid. Acephate and imidacloprid are systemic insecticides while dichlorvos has a contact/respiratory mode of action. The insecticidal preparations used were commercial formulations of acephate, Orthene $75 \% \mathrm{SP}$ (Chevron ChemicalCo., Richmond, Calif.) and of dichlorvos, Vaportape II (a.i. = 10\%, Hercon Environmental Co., Emigsville, Pa.) and two formulations of imidacloprid, a technical grade $($ a.i. $=98.3 \%)$ and a commercial formulation, Admire (a.i. $=21.4 \%$, Bayer Corp., Kansas City, Mo.).

Phytotoxicity bioassay. Shoot tip explants from well-established shoot cultures ( 3 weeks after subculture) were transferred to treated medium to determine the phytotoxicity of the insecticides. The technical grade and commercial formulation of imidacloprid and commercial formulation of acephate, were dissolved in dimethyl sulfoxide (Sigma Chemical Co., St. Louis) and added to autoclaved shoot culture medium cooled to $55^{\circ} \mathrm{C}$, to give final concentrations of $1,5,10,20,40$ or $80 \mathrm{mg} \cdot \mathrm{L}^{-1}$ a.i. One hundred milliliters of medium was dispensed into 500-mL culture jars. For the dichlorvos bioassay, pieces of Vaportape II measuring $4,9,16,25$, or $36 \mathrm{~mm}^{2}$ were used. This corresponded to $0.7,1.6,2.8,4.4$ and 6.4 $\mathrm{mg}$ a.i. of dichlorvos, respectively. One piece of Vaportape II, suspended from the foam plug in the lid, was used per jar. It was sterilized by dipping in $70 \%$ alcohol for $20 \mathrm{~s}$. Control cultures were grown on medium without insecticide added.

Shoot tip explants $\approx 2 \mathrm{~cm}$ long, placed five per jar with five jars per treatment, were inoculated into the various treatments and allowed to grow 6 weeks. The fresh weights of the shoot tip explants were recorded at the start of the incubation period and the fresh weights of shoot clusters that developed from these shoot tip explants were recorded at the end of the 6-week treatment period.

Insecticidal bioassay. Because all shoots remained alive in the phytotoxicity bioassays, experiments were done to determine the insecticidal efficacy of the various compounds using identical treatments to those described above for the phytotoxicity bioassay.

Shoot tip explants were cultured in the various treatments for 2 weeks before inocu- 
lation with thrips. Inoculation with thrips was accomplished by placing one infested shoot in each culture jar. The number of thrips per infested inoculum shoot averaged 50. This was determined in a separate, preliminary experiment by placing 20 infested shoots in individual sealed plastic bags for 3 weeks. This allowed the shoot to remain healthy but was sufficient time for thrips eggs on the inoculum to hatch. The number of thrips was counted after 3 weeks by washing the thrips off the shoots and bag with ethanol, collecting the ethanol in a petri dish and counting the insects using a stereo microscope. From this experiment, it was determined that an average of 50 adult thrips can develop over a 3-week period. The exact number of thrips inoculated to each culture jar replicate was not crucial since by the end of the treatment period the treatments resulted either in control with no multiplication nor thrip damage symptoms or severe infestations.

Shoot culture medium and incubation conditions were identical to those described above for maintaining the stock cultures. Cultures were observed for thrip damage at 4-week intervals, when subcultured, for a total time period of 12 weeks. This experiment was duplicated. After 12 weeks, shoot clusters of all treatments were removed from the culture jars, placed in Petri dishes which were sealed with Parafilm and observed with a stereo microscope for the presence of live thrips.

Data collection and statistical analysis. Shoot tip explant fresh weights were recorded in the phytotoxicity bioassay experiments at the start and shoot cluster fresh weights at the end of the experiments. The total weight of the five shoot tip explants/shoot clusters in each of the replicate jars was recorded. Also, the lengths of the main shoots in the shoot clusters and the number of shoots $>1 \mathrm{~cm}$ in each cluster were recorded. The overall condition of the cultures were assessed visually to note untoward detrimental effects on the quality of the cultures caused by the treatments. Visual assessments were used to record reduction in culture quality resulting from chlorosis, tip burn, condition of the stems and leaves, and vigor of the cultures. For the insecticide efficacy tests, shoot damage was assessed visually by estimating the percentage of total shoot surface mottled by feeding. Data were analyzed using analysis of variance (ANOVA), with pairwise comparisons of the means using Bonferroni's method (Neter et al., 1990).

\section{Results and Discussion}

Phytotoxicity bioassay. Treatments with the technical grade of imidacloprid did not significantly affect the means of shoot cluster fresh weights, number of shoots per cluster, or length of the main shoots. Visual assessment of the cultures suggested the treatments did not cause obvious dehabilitating effects on culture quality (Table 1).

With the commercial formulation of imidacloprid (Admire), the means of shoot cluster fresh weights of treatments at 1 and $80 \mathrm{mg} \cdot \mathrm{L}^{-1}$ differed significantly from the means of all other treatments (Table 2). The 20 to $80 \mathrm{mg} \cdot \mathrm{L}^{-1}$ treatments induced chlorosis and reduced shoot proliferation, as measured by the number of shoots at the end of the treatment period (Table 2). This adverse effect of Admire on the shoot cultures was attributed to unidentified components other than the a.i. in the commercial formulation since it was not observed in cultures treated with the technical grade. However, even at $80 \mathrm{mg} \cdot \mathrm{L}^{-1}$ all shoots survived and grew reasonably well and recovered when transferred to insecticide-free medium. Callus formed on the stems in the $80 \mathrm{mg} \cdot \mathrm{L}^{-1}$ treatment.

The means of fresh weights of shoot clusters treated with acephate (Orthene) was not affected by the treatments except the

Table 1. Effect of imidacloprid (technical formulation) on shoot cultures of apple after a 6-week treatment period.

\begin{tabular}{lccccc}
\hline & & \multicolumn{3}{c}{ Mean $^{\mathrm{z}}$} & \\
\cline { 3 - 4 } $\begin{array}{l}\text { Treatment } \\
\left(\mathrm{mg} \cdot \mathrm{L}^{-1}\right)\end{array}$ & $\begin{array}{c}\text { Shoot } \\
\text { quality }\end{array}$ & $\begin{array}{c}\text { Length of main } \\
\text { shoots in cluster } \\
(\mathrm{cm})^{\mathrm{y}}\end{array}$ & $\begin{array}{c}\text { No. of shoots } \\
\text { in cluster }\end{array}$ & $\begin{array}{c}\text { Shoot cluster } \\
\text { fresh wt } \\
(\mathrm{g})^{\mathrm{y}}\end{array}$ & $\begin{array}{c}\text { Estimated } \\
\text { shoot damage } \\
(\%)^{\mathrm{x}}\end{array}$ \\
\hline 0 & normal & $4.0 \pm 0.5 \mathrm{a}$ & $6.0 \pm 2.4 \mathrm{a}$ & $8.5 \pm \mathrm{a}$ & 100 \\
1 & normal & $4.2 \pm 0.6 \mathrm{a}$ & $5.8 \pm 1.5 \mathrm{a}$ & $7.1 \pm \mathrm{a}$ & 50 \\
5 & normal & $4.4 \pm 0.5 \mathrm{a}$ & $5.6 \pm 1.6 \mathrm{a}$ & $6.5 \pm \mathrm{a}$ & 0 \\
10 & normal & $4.2 \pm 0.6 \mathrm{a}$ & $5.6 \pm 1.4 \mathrm{a}$ & $6.8 \pm \mathrm{a}$ & 0 \\
20 & normal & $6.3 \pm 1.6 \mathrm{~b}$ & $6.4 \pm 1.2 \mathrm{a}$ & $7.3 \pm \mathrm{a}$ & 0 \\
40 & normal & $5.2 \pm 0.3 \mathrm{a}$ & $6.0 \pm 1.4 \mathrm{a}$ & $8.4 \pm \mathrm{a}$ & 0 \\
80 & normal & $5.1 \pm 0.5 \mathrm{a}$ & $5.4 \pm 1.0 \mathrm{a}$ & $7.3 \pm \mathrm{a}$ & 0 \\
\hline
\end{tabular}

${ }^{2}$ Means of length of main shoot in cluster, number of shoots in cluster $>1 \mathrm{~cm}$, and shoot cluster fresh weight.

${ }^{y}$ Mean separation within columns by Bonferroni's pairwise comparison at 0.05 . Means in each column followed by the same letters are not significantly different.

${ }^{x}$ Visual estimate of shoot surfaces mottled by feeding.

Table 2. Effect of imidacloprid (commercial formulation, Admire) on shoot cultures of apple after a 6-week treatment period.

\begin{tabular}{lccccc}
\hline & & \multicolumn{3}{c}{ Mean $^{\mathrm{z}}$} & \\
\cline { 3 - 5 } $\begin{array}{l}\text { Treatment } \\
\left(\mathrm{mg} \cdot \mathrm{L}^{-1}\right)\end{array}$ & $\begin{array}{c}\text { Shoot } \\
\text { quality }\end{array}$ & $\begin{array}{c}\text { Length of main } \\
\text { shoots in cluster } \\
(\mathrm{cm})^{\mathrm{y}}\end{array}$ & $\begin{array}{c}\text { No. of } \\
\text { shoots in } \\
\text { cluster }^{\mathrm{y}}\end{array}$ & $\begin{array}{c}\text { Shoot cluster } \\
\text { fresh wt } \\
(\mathrm{g})^{\mathrm{y}}\end{array}$ & $\begin{array}{c}\text { Estimated } \\
\text { shoot damage } \\
(\%)^{\mathrm{x}}\end{array}$ \\
\hline 0 & normal & $4.4 \pm 0.7 \mathrm{a}$ & $7.4 \pm 1.8 \mathrm{a}$ & $8.5 \pm 3.1 \mathrm{a}$ & 100 \\
1 & normal & $4.0 \pm 0.7 \mathrm{a}$ & $5.2 \pm 1.3 \mathrm{a}$ & $5.2 \pm 1.5 \mathrm{~b}$ & 70 \\
5 & normal & $4.1 \pm 0.4 \mathrm{a}$ & $5.4 \pm 1.0 \mathrm{a}$ & $6.6 \pm 0.9 \mathrm{a}$ & 0 \\
10 & norma & $13.4 \pm 0.3 \mathrm{a}$ & $5.8 \pm 1.3 \mathrm{a}$ & $6.3 \pm 1.2 \mathrm{a}$ & 0 \\
2 & chlorotic & $3.4 \pm 0.4 \mathrm{a}$ & $3.6 \pm 0.5 \mathrm{~b}$ & $6.0 \pm 0.9 \mathrm{a}$ & 0 \\
40 & chlorotic & $3.2 \pm 0.4 \mathrm{a}$ & $3.8 \pm 1.5 \mathrm{~b}$ & $5.7 \pm 1.4 \mathrm{a}$ & 0 \\
80 & $\begin{array}{c}\text { chlorotic } \\
\text { with callus }\end{array}$ & $3.1 \pm 0.5 \mathrm{~b}$ & $3.2 \pm 1.5 \mathrm{~b}$ & $4.5 \pm 0.7 \mathrm{~b}$ & 0
\end{tabular}

${ }^{2}$ Means of length of main shoot in clusters, number of shoots in clusters $>1 \mathrm{~cm}$ and shoot cluster fresh weights.

yMean separation within columns by Bonferroni's pairwise comparison at 0.05 . Means in each column followed by the same letters are not significantly different.

${ }^{x}$ Visual estimate of shoot surfaces mottled by feeding.

Table 3. Effect of acephate (commercial formulation, Orthene) on shoot cultures of apple after a 6-week treatment period.

\begin{tabular}{lccccc}
\hline & & \multicolumn{3}{c}{ Mean $^{z}$} & \\
\cline { 3 - 4 } $\begin{array}{l}\text { Treatment } \\
\left(\mathrm{mg} \cdot \mathrm{L}^{-1}\right)\end{array}$ & $\begin{array}{c}\text { Shoot } \\
\text { quality }\end{array}$ & $\begin{array}{c}\text { Length of main } \\
\text { shoots in cluster } \\
(\mathrm{cm})^{\mathrm{y}}\end{array}$ & $\begin{array}{c}\text { No. of } \\
\text { shoots in } \\
\text { cluster }^{\mathrm{y}}\end{array}$ & $\begin{array}{c}\text { Shoot cluster } \\
\text { fresh wt } \\
(\mathrm{g})^{\mathrm{y}}\end{array}$ & $\begin{array}{c}\text { Estimated } \\
\text { shoot damage } \\
(\%)^{\mathrm{x}}\end{array}$ \\
\hline 0 & normal & $\begin{array}{c}4.5 \pm 0.6 \mathrm{a} \\
4.4 \pm 0.7 \mathrm{a}\end{array}$ & $6.8 \pm 1.3 \mathrm{a}$ & $6.9 \pm 0.6 \mathrm{a}$ & 100 \\
5 & normal & $4.4 \pm 0.5 \mathrm{a}$ & 5 \\
10 & normal & $4.4 \pm 0.6 \mathrm{a}$ & $6.4 \pm 1.0 \mathrm{a}$ & $6.7 \pm 1.4 \mathrm{a}$ & 0 \\
20 & normal & $3.8 \pm 0.2 \mathrm{a}$ & $5.8 \pm 0.7 \mathrm{a}$ & $7.1 \pm 2.0 \mathrm{~b}$ & 0 \\
40 & normal & $3.8 \pm 0.7 \mathrm{a}$ & $5.2 \pm 1.3 \mathrm{a}$ & $5.6 \pm 0.9 \mathrm{a}$ & 0 \\
80 & normal & $3.9 \pm 0.6 \mathrm{a}$ & $4.4 \pm 1.0 \mathrm{~b}$ & $5.2 \pm 1.1 \mathrm{a}$ & 0 \\
\hline
\end{tabular}

${ }^{\mathrm{z}}$ Means of length of main shoot in cluster, number of shoots in cluster $>1 \mathrm{~cm}$ and shoot cluster fresh weight.

${ }^{y}$ Mean separation within columns by Bonferroni's pairwise comparison at 0.05 . Means in each column followed by the same letters are not significantly different.

${ }^{x}$ Visual estimate of shoot surfaces mottled by feeding. 
of thrip damage. In contrast, control cultures with no insecticide treatment had $100 \%$ shoot damage with death, indicated by browning and loss of cell turgor of most tissues not protected by submersion in the medium (Fig. 1).

Eight weeks after inoculation, some of the treated shoots had developed thrip damage. Five percent of shoots cultured in the $1 \mathrm{mg} \cdot \mathrm{L}^{-1}$ treatments of both acephate and technical grade of imidacloprid, developed symptoms of thrip damage, while $30 \%$ to $40 \%$ damage occurred to shoots cultured in the $1 \mathrm{mg} \cdot \mathrm{L}^{-1}$ commercial formulation of imidacloprid (Admire). None of the other treatments showed any symptoms of thrip damage.

After 12 weeks, $50 \%$ damage had occurred in the $1 \mathrm{mg} \cdot \mathrm{L}^{-1}$ treatments with the technical grade and $70 \%$ damage with the commercial formulation of imidacloprid, but damage remained at $5 \%$ in the $1 \mathrm{mg} \cdot \mathrm{L}^{-1}$ acephate treatment. This suggested that with the $1 \mathrm{mg} \cdot \mathrm{L}^{-1}$ acephate treatment, shoot damage was caused initially by the thrips inoculated into the culture but thrip multiplication was prevented. No symptoms of thrip damage were seen in any of the treatments at concentrations of $5 \mathrm{mg} \cdot \mathrm{L}^{-1}$ or greater. When examined under the microscope, live thrips were observed only on shoots treated with $1 \mathrm{mg} \cdot \mathrm{L}^{-1}$ of the technical grade and commercial formulation of imidacloprid. No live thrips were observed on shoots treated with $1 \mathrm{mg} \cdot \mathrm{L}^{-1}$ acephate or on shoots of any of the other treatment.

Acephate and imidacloprid are systemic insecticides with low mammalian toxicity and low phytotoxicity (Bath Press, 1994). This, combined with the results presented above, indicate they are good candidates for use in tissue culture to control or eliminate thrip infestations. They were effective at the low concentrations used in these experiments and had no apparent deleterious effects on apple cultures even when cultures were treated for three subculture periods ( 12 weeks). One milligram per liter of both the technical grade and commercial formulation of imidacloprid were not effective in eradicating the thrips. However, eradication was achieved at $5 \mathrm{mg} \cdot \mathrm{L}^{-1}$ and above.

No symptoms of thrip damage were seen at any treatment level in cultures treated with dichlorvos (Vaportape II). However, visual assessment of cultures suggested a progressive decline in quality towards the end of the experiment at the two highest treatment concentrations. Shoots tips in the $6.4 \mathrm{mg}$ treatment died and associated brown tissue developed (Fig. 1).

Dichlorvos has a respiratory, contact and stomach mode of action. It has high volatility and is known to rapidly kill insects, but it also has high mammalian toxicity and may also be phytotoxic to some plants (Bath Press, 1994). Dichlorvos was highly phytotoxic to sweet cherry cultures in some preliminary experiments (results not shown). With apple cultures, $0.7 \mathrm{mg}$ dichlorvos $/ 500 \mathrm{~mL}$ culture jar controlled thrips with $100 \%$ effectiveness, with little negative effect on the growth of shoot cultures or their quality assessed visually, but prolonged exposure ( $>6$ weeks) to high con-
Table 4. Effect of dichlorvos (commercial formulation, Vaportape II) on shoot cultures of apple after a 6-week treatment period.

\begin{tabular}{|c|c|c|c|c|c|}
\hline \multirow[b]{2}{*}{$\begin{array}{l}\text { Treatment } \\
\left(\mathrm{mg} \cdot \mathrm{L}^{-1}\right)\end{array}$} & \multirow[b]{2}{*}{$\begin{array}{l}\text { Shoot } \\
\text { quality }\end{array}$} & \multicolumn{3}{|c|}{ Mean $^{2}$} & \multirow[b]{2}{*}{$\begin{array}{c}\text { Estimated } \\
\text { shoot damage } \\
(\%)^{\mathrm{x}}\end{array}$} \\
\hline & & $\begin{array}{l}\text { Length of main } \\
\text { shoots in cluster } \\
(\mathrm{cm})^{\mathrm{y}}\end{array}$ & $\begin{array}{l}\text { No. of } \\
\text { shoots in } \\
\text { cluster }^{y}\end{array}$ & $\begin{array}{l}\text { Shoot cluster } \\
\text { fresh wt } \\
(\mathrm{g})^{\mathrm{y}}\end{array}$ & \\
\hline 0 & normal & $4.0 \pm 0.8 \mathrm{a}$ & $6.8 \pm 2.2 \mathrm{a}$ & $3.3 \pm 0.6 \mathrm{a}$ & 100 \\
\hline 0.7 & small leaves & $3.9 \pm 0.7 \mathrm{ab}$ & $4.0 \pm 0.9 \mathrm{a}$ & $2.8 \pm 0.6 \mathrm{a}$ & 0 \\
\hline 1.6 & small leaves & $2.8 \pm 0.5 \mathrm{c}$ & $3.6 \pm 0.8 \mathrm{a}$ & $3.0 \pm 0.6 \mathrm{a}$ & 0 \\
\hline 2.8 & small leaves & $3.0 \pm 0.6 \mathrm{c}$ & $4.0 \pm 0.9 \mathrm{a}$ & $2.7 \pm 0.4 \mathrm{a}$ & 0 \\
\hline 4.4 & small leaves & $3.0 \pm 0.4 \mathrm{c}$ & $3.2 \pm 1.2 \mathrm{~b}$ & $2.9 \pm 0.3 \mathrm{a}$ & 0 \\
\hline 6.4 & small leaves & $2.8 \pm 0.5 \mathrm{c}$ & $3.2 \pm 2.2 \mathrm{~b}$ & $2.6 \pm 0.1 \mathrm{a}$ & 0 \\
\hline
\end{tabular}

${ }^{\mathrm{z}}$ Means of length of main shoot in cluster, number of shoots in cluster $>1 \mathrm{~cm}$ and shoot cluster fresh weight.

yean separation within columns by Bonferroni's pairwise comparison at 0.05 . Means in each column followed by the same letters are not significantly different.

${ }^{\mathrm{x}}$ Visual estimate of shoot surfaces mottled by feeding.

centrations was deleterious. The low dose of $0.7 \mathrm{mg} / \mathrm{jar}$ was found to give $100 \%$ control of thrips in our studies and may or may not be a health hazard depending on the number of jars treated, ventilation and other factors.

The thrips used as inoculum in this study appeared to be free of bacteria and fungal spores since no cultures became contaminated with bacteria or fungi. Shoot cultures with thrip damage symptoms were always infested with large numbers of thrips that had multiplied from the original inoculum. By the end of the

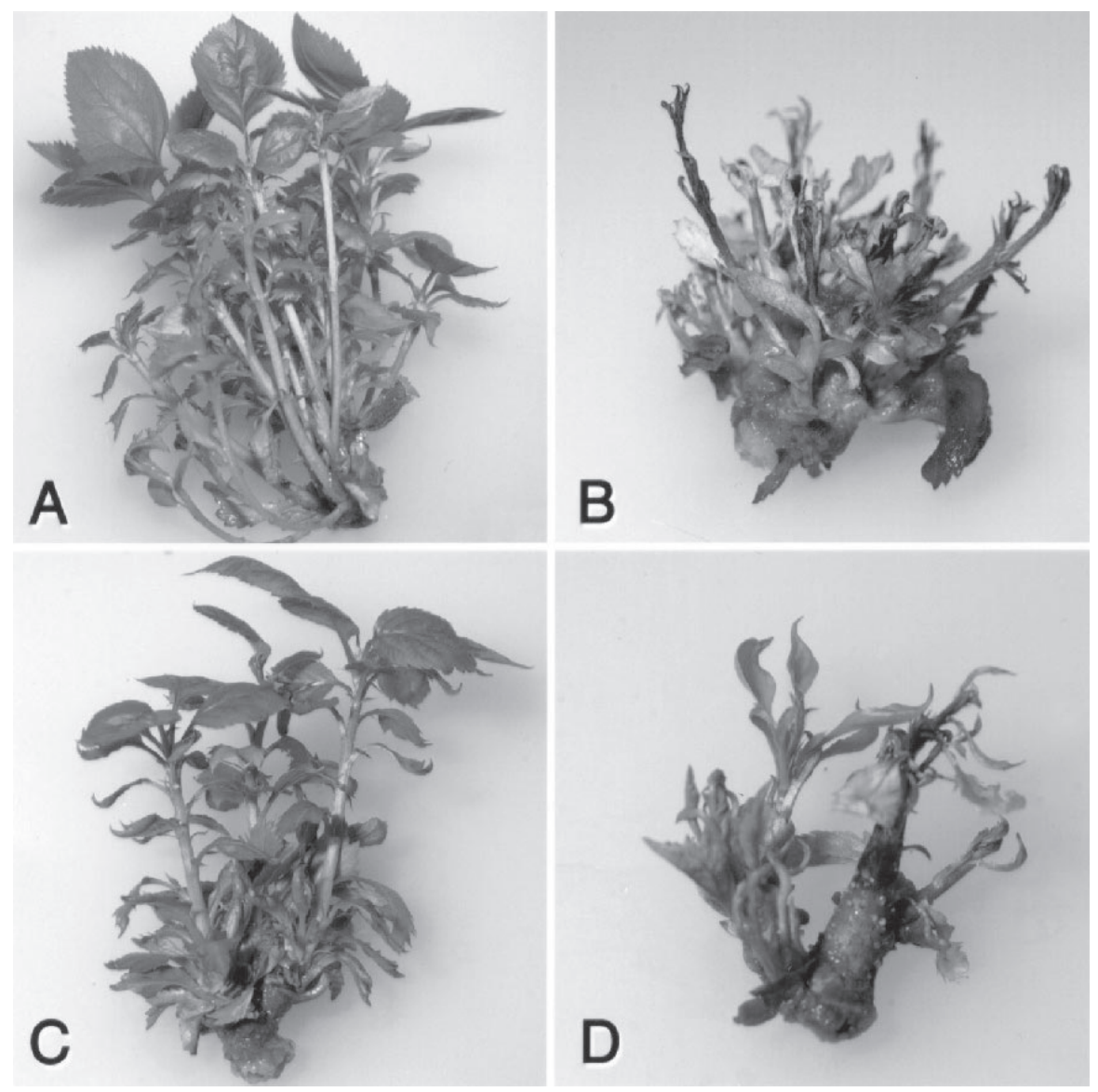

third subculture (12 weeks), shoot cultures were either infested because the treatment was not effective or were thrip-free and did not become infested when transferred to insecticide-free medium indicating that the insects introduced with the inoculum plus insects developing from eggs on the inoculum had been killed.

To achieve complete eradication of thrips from in vitro cultures with insecticides used in this way, the duration of treatment should be long enough so that insects emerging from eggs are killed and do not reinitiate the infestation.
Fig. 1. Effect of insecticide treatment and inoculation with thrips on in vitro shoots of 'Golden Delicious'after 12 weeks of culture. (A) control, untreated and uninoculated; (B) control, untreated and inoculated with thrips (note damage to upper portions of shoots not submerged in the medium); $(\mathbf{C})$ treated with $80 \mathrm{mg} \cdot \mathrm{L}^{-1}$ imidacloprid (technical grade) and inoculated; (D) treated with $6.4 \mathrm{mg}$ dichlorvos $/ 500-\mathrm{mL}$ culture jar and inoculated (note phytotoxicity and reduced shoot proliferation caused by the treatment after 12 weeks). 
Insecticidal treatment of our apple cultures for two subculture periods (6 weeks) resulted in eradication of the thrips and cultures returned to optimum growth and quality in the subculture period following cessation of treatment. The chemicals used in these experiments are, to our knowledge, not registered for use with in vitro plant cultures.

\section{Literature Cited}

Bath Press. 1994. In: C. Tomlin, (ed.). The pesticide manual, $10^{\text {th }}$ edition. Acephate, p. 9-10; Dichlorvos, p. 313-314; Imidacloprid, p. 591-593. Bath, U.K.

Blake, J. 1988. Mites and thrips as bacterial and fungal vectors between plant tissue cultures. Acta Hort. 225: 163-166.
Boxus, P.H. and J.M. Terzi. 1987. Big losses due to bacterial contamination can be avoided in mass propagation scheme. Acta Hort. 212:91-93.

Cassells, A.C. 1986. Production of healthy plants. p. 53-71. In: P.G. Alderson and W.M. Dullforce (eds.). Proc. Inst. Hort. Symp.: Micropropagation in Hort. Univ. of Nottingham, Trent Print Unit, Nottingham, U.K.

Deberch, P. and I. Maene. 1984. Pathological and physiological problems related to the in vitro culture of plants. Parasitica. 40:69-75.

Klocke, J.A. and P. Myers. 1984. Chemical control of thrips on cultured Simmondsia chinensis (Jojoba) shoots. HortScience 19:400.

Knauss, J.F. and J.M. Miller 1978. A contaminant, Erwinia carotovora, affecting commercial plant tissue cultures. In Vitro. 14:754-756.

Leifert, C. and W.M. Waites. 1990. Contamination of plant tissue cultures. Intl. Assoc. for Plant Tissue Culture, Nwsl. 60:2-13.

Leifert, C. and S. Woodward. 1998. Laboratory contamination management: The requirement for microbiological quality assurance. Plant Cell Tissue Org. Cult. 52: 83-88.

Leifert, C., C.E. Morris, and W.M. Waites. 1994. Ecology of microbial saprophytes and pathogens in tissue culture and field-grown plants: Reasons for contamination problems in vitro. Critical Reviews in Plant Sci. 13:139-183.

Murashige, T. and F. Skoog. 1962. A revised medium for rapid growth and bioassays with tobacco tissue cultures. Physiol. Plant. 15: 473-497.

Neter, J., W. Wasserman, and M.H. Kutner. 1990. Applied linear statistical models, $3^{\text {rd }}$ edition, $p$. 741-744. Irwin Publishing, Toronto. 